\title{
Identification of the biologically active constituents of Camellia japonica leaf and anti-hyperuricemic effect in vitro and in vivo
}

\author{
IN-SOO YOON $^{1 *}$, DAE-HUN PARK ${ }^{2 *}$, JUNG-EUN KIM $^{3}$, JIN-CHEOL YOO $^{4}$, MIN-SUK BAE $^{5}$, DEUK-SIL OH ${ }^{6}$,

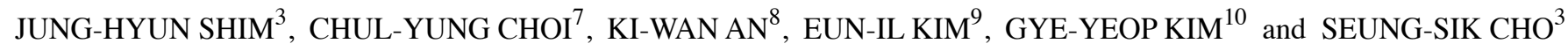 \\ ${ }^{1}$ College of Pharmacy, Pusan National University, Geumjeong, Busan 46241; ${ }^{2}$ Department of Oriental Medicine Materials, \\ Dongshin University, Naju, Jeonnam 58245; ${ }^{3}$ Department of Pharmacy, College of Pharmacy and Natural Medicine Research Institute, \\ Mokpo National University, Muan, Jeonnam 58554; ${ }^{4}$ Department of Pharmacy, College of Pharmacy, Chosun University, \\ Gwangju 61452; ${ }^{5}$ Department of Environmental Engineering, Mokpo National University, Muan, Jeonnam 58554; \\ ${ }^{6}$ Jeollanamdo Wando Arboretum, Wando, Jeonnam 59105; ${ }^{7}$ Jeonnam Bioindustry Foundation, Institute of Natural Resources Research, \\ Jangheung, Jeonnam 59338; ${ }^{8}$ Division of Forest Resources, College of Agriculture and Life Sciences, Chonnam National University; \\ ${ }^{9}$ Department of Landscape Architecture, College of Agriculture and Life Sciences, Chonnam National University, \\ Gwangju 61186; ${ }^{10}$ Department of Physical Therapy, College of Health and Welfare, \\ Dongshin University, Naju, Jeonnam 58245, Republic of Korea
}

Received September 21, 2016; Accepted April 26, 2017

DOI: 10.3892/ijmm.2017.2973

\begin{abstract}
Camellia japonica L. is a plant of which the seeds are used as a folk medicine, and it is native to South Korea, Japan and China. In previous study, triterpenes, flavonoids, tannins and fatty acids which have antiviral, antioxidant and anti inflammatory activity were reported from $C$. japonica leaf and flower. In Korea, the seed from this plant is used as a traditional medicine and in folk remedies for the treatment of bleeding and inflammation. However, the major issue associated with the use of the seed as a medicinal and/or functional food ingredient is its application to the pharmaceutical and food industry. First, the productivity of seed extract is very much less than that of the leaf. Second, the beneficial usage of the seed extract as an alternative medicine and functional source is not yet clear. Thus, in this study, we focused on another part of the plant, the leaf, and found that the extract of Camellia japonica leaf has a high concentration of vitamin $\mathrm{E}$, rutin and other biologically active compounds related to hyperuricemia. We aimed to investigate the biological activities, namely the antioxidant activities, xanthine oxidase (XO) inhibitory activity and anti-hyperuricemic effects of extract from C. japonica leaf
\end{abstract}

Correspondence to: Professor Seung-Sik Cho, Department of Pharmacy, College of Pharmacy and Natural Medicine Research Institute, Mokpo National University, 1666 Youngsan-ro, Muan, Jeonnam 58554, Republic of Korea

E-mail: sscho@mokpo.ac.kr

${ }^{*}$ Contributed equally

Key words: Camellia japonica leaf, xanthine oxidase, hyperuricemia, gas chromatography-mass spectrometry, high-performance liquid chromatography and the phytochemicals contained therein. Ethanol extracts of $C$. japonica leaf (ECJL) were prepared, and the extract was used with respect to antioxidant activities, total phenolic contents and XO inhibitory activity. The in vivo XO inhibitory activity and anti-hyperuricemic effects of the extract were evaluated in mice with potassium oxonate-induced hyperuricemia. To clarify the marker compounds that are responsible for the anti-hyperuricemic effects, several key constituents were identified using gas chromatography-mass spectrometry (GC-MS) and and liquid chromatography-mass spectrometry (LC-MS). ECJL was found to have strong antioxidant activities, and in vitro $\mathrm{XO}$ inhibitory activity. The results of the in vivo experiments using mice demonstrated that ECJL at the doses of 100 and $300 \mathrm{mg} / \mathrm{kg}$ inhibited hepatic XO activity and significantly attenuated hyperuricemia. To the best of our knowledge, the present study is the first report on the XO inhibitory and anti-hyperuricemic effects of ECJL, which can be therapeutically applied in the treatment of hyperuricemia and gout.

\section{Introduction}

Camellia japonica L. (C. japonica) is a tree belonging to the Theaceae family and is cultivated and has been used in traditional medicine in Japan, China, and Korea for the treatment of stomachic illness, bleeding and inflammation $(1,2)$. The usage of the seed and flower from C. japonica was first reported in 'Dongui Bogam' which was thought to have been written by the doctor of oriental medicine, Heo Jun in 1613 (3).

C. japonica is a perennial herb that grows in forests in the southern region of Korea. Recently, the northern limits of C. japonica have widely increased due to the greenhouse effect on Earth's atmosphere in South Korea (4). Additionally, the provincial governments of South Korea have made many efforts to industrialize $C$. japonica in the field of food and medicinal 
sources. From 2004, green tea from $C$. japonica has been developed as a food source in Korea so called 'Dong-Baek Cha' which was commercialized in 2007 (5). However, the specific and beneficial usage of the leaf as a functional food source and/or plant medicine has not yet been determined.

Chemically, this species has shown to be constituted of triterpenes, saponins, glycosylated flavonoids and tannins (1,6-8). Several of these derivatives have been shown to exhibit biological activity, such as antioxidant (7), antifungal (9), antiviral (10) and cytotoxic potential (8).

In our preliminary experiments, we screened approximately 500 plant extracts and selected the extract of $C$.japonica leaf as a xanthine oxidase (XO) inhibitor to find an alternative medicine for hyperuricemia. We investigated the active constituents and the biological activities of extracts from $C$. japonica leaf for the development of possible alternatives to allopurinol.

Hyperuricemia is a condition in which the levels of uric acid in the blood exceed the normal range, which is due to the regular intake of food with a high purine content and is invariably accompanied by gout, chronic kidney disease and other metabolic syndromes (11). Uric acid is the final metabolite of the purine compound, which is formed by the oxidation of hypoxanthine to xanthine and xanthine to uric acid by XO (12). The overproduction of uric acid by XO leads to hyperuricemia, which is the main cause of gout. Gout is a metabolic disorder that is closely associated with high levels of uric acid in the body, which can cause inflammation, gouty arthritis and uric acid nephrolithiasis (13). Gout has been reported to afflict $>2$ million men and women in the US alone (14). The prevalence of gout is rapidly increasing in other regions, including Northeast Asia (15), likely due to changes in dietary habits.

The aim of the present study was to investigate the potential of extract of $C$. japonica leaf (ECJL) to inhibit XO and to act as an antioxidant in vitro and in vivo. Moreover, the extract was investigated for its effects on the elimination of uric acid in serum and the inhibition of XO in mice with potassium oxonate-induced hyperuricemia. Screening of the extract for its $\mathrm{XO}$ inhibitory activity followed by their potential to reduce serum uric acid levels and XO activity may play an important role in identifying a potent chemical entity for the treatment of gout and related inflammatory disorders. To clarify the biological marker in ECJL, we describe the identification of bioactive constituents that include rutin, vitamin $\mathrm{E}$, all-trans-squalene, neophytadiene, linolenic acid, n-hexadecanoic acid, n-octacosane, n-eicosane, and 6,9-pentadecadien-1-ol using gas chromatography-mass spectrometry (GC-MS) and high-performance liquid chromatography (HPLC) analysis.

\section{Materials and methods}

Plant materials. The leaves of $C$. japonica were provided from Jeollanamdo Wando Arboretum, in Jeonnam, Korea. C. japonica leaves were collected on Joyag island, Korea (126 56'50.07"E longitude and 34 $22^{\prime} 31.27^{\prime \prime} \mathrm{N}$ latitude). A voucher specimen (MNUCSS-CJ-01) was deposited at Mokpo National University (Muan, Korea). The leaves were separated for use in the present study. The air-dried and powdered $C$.japonica leaf $(10 \mathrm{~g})$ was extracted twice with ethanol $(100 \mathrm{ml})$ at room temperature for 3 days. The resultant ethanol solution was evaporated, dried and stored at $-50^{\circ} \mathrm{C}$. The sample was used for in vitro and in vivo experiments, and for the analysis of the active constituents.

Animals. Male ICR mice (4 weeks old) were purchased from Orient Bio Co. (Sungnam, Korea). The mice were retained in a clean room at a temperature of $20-23^{\circ} \mathrm{C}$ with 12 -h light (07:00-19:00) and dark (19:00-07:00) cycles, and a relative humidity of $50 \pm 5 \%$. The mice were housed in ventilated mice cages (Tecniplast, West Chester, PA, USA) under filtered and pathogen-free air, with food (Agribrands Purina Korea, Inc., Seoul, Korea) and water available ad libitum. All animal experiments were carried out according to the guidelines of the Animal Investigation Committee of Jeonnam Bioindustry Foundation (Naju, Korea) (approval no. JINR1517).

Profiling of constituents by GC-MS analysis. The analytical methods for the analysis based on GC-MS have been previously reported (16). The analysis of scanned organic compounds was performed using an Agilent 7890 Gas Chromatograph System, coupled to a quadrupole Agilent 5975C electron ionization (EI) $(70 \mathrm{eV})$ mass spectrometric detector (Agilent Technologies, Inc., Palo Alto, CA, USA). An Agilent HP-5MS fused silica capillary column (30 m x $0.25 \mathrm{~mm}$ i.d., $0.25 \mu \mathrm{m}$ film thickness) was utilized for the identification of organic compounds. Briefly GC-MS was tuned using perfluorotribuylamine (PFTBA) by mass fragments of 69.0, 219.0, $502.0 \mathrm{~m} / \mathrm{z}$ under EI conditions. The $\mathrm{GC}$ oven was heated using the following program: isothermal at $65^{\circ} \mathrm{C}$ for $10 \mathrm{~min}$ and $10 \mathrm{~min}^{-1}$ to $300^{\circ} \mathrm{C}$ with $\mathrm{He}$ as the carrier gas. The transfer line was heated at $300^{\circ} \mathrm{C}$, and the mass spectrometer was then operated in scan mode (50-550 amu). All mass spectra were compared with the data system library (NIST 2008). The summarized operation parameters for the GC are shown in Table I.

Profiling of constituents by HPLC analysis. Constituent profiling of ECJL was performed with HPLC. All HPLC analyses were performed using the Alliance 2695 HPLC System (Waters Corp., Millford, MA, USA) equipped with a photodiode array detector. The Agilent ZORBAX Extend-C18 (5 $\mu \mathrm{m}, 150 \mathrm{~mm}$ 1. x $5 \mathrm{~mm}$ i.d.) analytical column was used with a mobile phase consisting of solvent A (acetonitrile) and solvent B (water containing $0.2 \%$ phosphoric acid). Gradient elution (from $10 / 90$ to $100 / 0, \mathrm{v} / \mathrm{v}$ ) was performed at a flow rate of $1.0 \mathrm{ml} / \mathrm{min}$ (Table II). Column temperature was maintained at $25^{\circ} \mathrm{C}$. The detection wavelength was set at $270 \mathrm{~nm}$ for rutin. The solvent was filtered through a $0.22-\mu \mathrm{m}$ filter and degassed. The sample injection volume was $10 \mu \mathrm{l}$.

2,2-Diphenyl-1-picrylhydrazyl (DPPH) free radical assay. The determination of the antioxidant activity of ECJL was performed by the DPPH radical scavenging method. DPPH radicals have an absorption maximum of $517 \mathrm{~nm}$, which disappears with reduction by an antioxidant compound. ECJL solution $(1 \mathrm{ml})$ containing 1-20 $\mathrm{mg}$ of ECJL was added to a $0.4 \mathrm{mM}$ DPPH ECJL solution $(1 \mathrm{ml})$. The solution was mixed and allowed to react at room temperature in the dark for $10 \mathrm{~min}$. The absorbance at $517 \mathrm{~nm}$ was measured using a microplate reader (PerkinElmer, Inc., Waltham, MA, USA). The radical scavenging activity was calculated as a percentage using the following equation: DPPH radical scavenging 
Table I. Analysis condition of GC-MS.

\begin{tabular}{|c|c|c|c|}
\hline Parameter & \multicolumn{3}{|c|}{ Condition } \\
\hline Column & \multicolumn{3}{|c|}{$\begin{array}{l}\text { Agilent HP-5MS fused silica } \\
\text { capillary column ( } 30 \mathrm{~m} \times 0.25 \mathrm{~mm} \text { i.d., } \\
0.25 \mu \mathrm{m} \text { film thickness })\end{array}$} \\
\hline Carrier & \multicolumn{3}{|c|}{ Helium } \\
\hline Split & \multicolumn{3}{|c|}{$1: 5$} \\
\hline Injection volume & \multicolumn{3}{|c|}{$1 \mu 1$} \\
\hline MS source & \multicolumn{3}{|c|}{$230^{\circ} \mathrm{C}$} \\
\hline MS quad & \multicolumn{3}{|c|}{$150^{\circ} \mathrm{C}$} \\
\hline Thermal aux & \multicolumn{3}{|c|}{$300^{\circ} \mathrm{C}$} \\
\hline Electron ionization & \multicolumn{3}{|c|}{$70 \mathrm{eV}$} \\
\hline Mass range & \multicolumn{3}{|c|}{$50-550 \mathrm{amu}$} \\
\hline Scan method & \multicolumn{3}{|c|}{ Full scan } \\
\hline & $\begin{array}{c}\text { Rate } \\
\left({ }^{\circ} \mathrm{C} / \mathrm{min}\right)\end{array}$ & $\begin{array}{l}\text { Value } \\
\left({ }^{\circ} \mathrm{C}\right)\end{array}$ & $\begin{array}{l}\text { Hold time } \\
\qquad(\min )\end{array}$ \\
\hline \multicolumn{4}{|c|}{ Analytical temperature } \\
\hline Initial & & 65 & 10 \\
\hline Ramp & 10 & 300 & 22 \\
\hline Total & 55.5 & & \\
\hline
\end{tabular}

GC-MS, gas chromatography-mass spectrometry.

activity $(\%)=\left[1-\left(\mathrm{A}_{\text {sample }} / \mathrm{A}_{\text {blank }}\right)\right] \times 100$. The DPPH free radical scavenging activities of the samples were compared in terms of their $\mathrm{IC}_{50}(\mu \mathrm{g} / \mathrm{ml})$ values, as previously described (17).

Determination of reducing power. The reducing power of ECJL was determined according to a modified reducing power assay method. The sample $(0.1 \mathrm{ml})$ was added to $0.2 \mathrm{M}$ sodium phosphate buffer $(0.5 \mathrm{ml})$ and $1 \%$ potassium ferricyanide $(0.5 \mathrm{ml})$, and this mixture was incubated at $50^{\circ} \mathrm{C}$ for $20 \mathrm{~min}$. Following incubation, $10 \%$ trichloroacetic acid solution $(0.5 \mathrm{ml})$ was added to the reaction mixture, and it was centrifuged at $12,000 \mathrm{rpm}$ for $10 \mathrm{~min}$. The supernatant was mixed with distilled water $(0.5 \mathrm{ml})$ and a $0.1 \%$ iron (III) chloride solution $(0.1 \mathrm{ml})$, and the absorbance at $700 \mathrm{~nm}$ of the resulting solution was measured. The reducing powers of the samples were expressed as vitamin $\mathrm{C}$ equivalents, as previously described (17).

Determination of total phenolic content. The total phenolic content was determined by Folin-Ciocalteu assay, as previously described (18). Water solution $(1 \mathrm{ml})$ containing $5 \mathrm{mg}$ of ECJL or standard was mixed with $1 \mathrm{ml}$ of $2 \%$ sodium carbonate solution and $1 \mathrm{ml}$ of $10 \%$ Folin-Ciocalteu's phenol reagent. After $10 \mathrm{~min}$, the absorbance was measured at $750 \mathrm{~nm}$ using a microplate reader (PerkinElmer, Inc.). The measurement was compared to calibration curve of gallic acid. The results were expressed as milligrams of gallic acid equivalents per gram of sample, as previously described (17).

Determination of $\mathrm{XO}$ inhibitory activity in vitro. The $\mathrm{XO}$ inhibitory activity was measured by monitoring uric acid
Table II. Analytical conditions of HPLC for analysis of ECJL.

\begin{tabular}{|c|c|c|c|}
\hline Parameters & \multicolumn{3}{|c|}{ Conditions } \\
\hline Column & \multicolumn{3}{|c|}{$\begin{array}{c}\text { Zorbax extended-C18 } \\
(\mathrm{C} 18,4.6 \mathrm{~mm} \times 150 \mathrm{~mm}, 5 \mu \mathrm{m})\end{array}$} \\
\hline Flow rate & \multicolumn{3}{|c|}{$1 \mathrm{ml} / \mathrm{min}$} \\
\hline Injection volumn & \multicolumn{3}{|c|}{$10 \mu 1$} \\
\hline UV detection & \multicolumn{3}{|c|}{$270 \mathrm{~nm}$} \\
\hline Run time & \multicolumn{3}{|c|}{$30 \mathrm{~min}$} \\
\hline & Time $(\min )$ & $\% \mathrm{~A}^{\mathrm{a}}$ & $\% \mathrm{~B}^{\mathrm{b}}$ \\
\hline \multirow[t]{7}{*}{ Gradient } & 0 & 90 & 10 \\
\hline & 7 & 90 & 10 \\
\hline & 15 & 70 & 30 \\
\hline & 22 & 70 & 30 \\
\hline & 25 & 0 & 100 \\
\hline & 30 & 90 & 10 \\
\hline & 35 & 90 & 10 \\
\hline
\end{tabular}

${ }^{\mathrm{a}} 0.2 \%$ Phosphoric acid; ${ }^{\mathrm{b}}$ acetonitrile. HPLC, high-performance liquid chromatography; ECJL, extracts of $C$. japonica leaf.

formation in a XO system, as previously described (19). The assay system consisted of $0.6 \mathrm{ml}$ phosphate buffer $(100 \mathrm{mM}$; $\mathrm{pH} 7.4), 0.1 \mathrm{ml}$ sample, $0.1 \mathrm{ml} \mathrm{XO}(0.2 \mathrm{U} / \mathrm{ml})$ and $0.2 \mathrm{ml}$ xanthine $(1 \mathrm{mM}$; dissolved in $0.1 \mathrm{~N} \mathrm{NaOH})$. The reaction was initiated by adding the enzyme with or without inhibitors, and the change in absorbance of the mixture at $290 \mathrm{~nm}$ for $15 \mathrm{~min}$ was measured against a reagent blank. A $0.2 \mathrm{ml}$ aliquot of $1 \mathrm{~N}$ $\mathrm{HCl}$ was used to terminate the enzymatic reaction. Allopurinol was used as a positive control.

Establishment of the mouse model of hyperuricemia and drug administration. Six groups of mice ( $\mathrm{n}=5$ for each group) were treated once daily for 7 days as follows: the mice in the 2 negative control groups (NOR and HU groups) received 0.3\% CMC-Na aqueous solution; the mice in the positive control group (ALLO group) received allopurinol solution at a dose of $10 \mathrm{mg} / \mathrm{kg}$; the mice in the ECJL 30, ECJL 100, and ECJL 300 groups received the ECJL solution at doses of 30,100 and $300 \mathrm{mg} / \mathrm{kg}$, respectively. Hyperuricemia was induced in the mice by potassium oxonate, a uricase inhibitor (20). Briefly, ECJL (30, 100 and $300 \mathrm{mg} / \mathrm{kg}$ ) or allopurinol $(10 \mathrm{mg} / \mathrm{kg}$ ) were dissolved in $0.3 \% \mathrm{CMC}-\mathrm{Na}$ aqueous solution. The resultant drug solutions were orally administered once per day for 7 days. Food, except water, was withdrawn from the mice at $1.5 \mathrm{~h}$ prior to drug administration, and the mice were intraperitoneally injected with potassium oxonate $(300 \mathrm{mg} / \mathrm{kg})$ $1 \mathrm{~h}$ before the final drug administration on the 7th day in order to induce hyperuricemia. Blood samples were collected via the tail vein of the mice at $1 \mathrm{~h}$ after the final drug administration on the 7th day. The blood samples were allowed to clot for approximately $1 \mathrm{~h}$ at room temperature and then centrifuged at $10,000 \times \mathrm{g}$ for $15 \mathrm{~min}$ to obtain serum. The serum samples were stored at $-80^{\circ} \mathrm{C}$ until use. The serum uric acid concentration was measured using standard diagnostic kits (Abcam, Cambridge, UK). Each assay was performed in triplicate. 


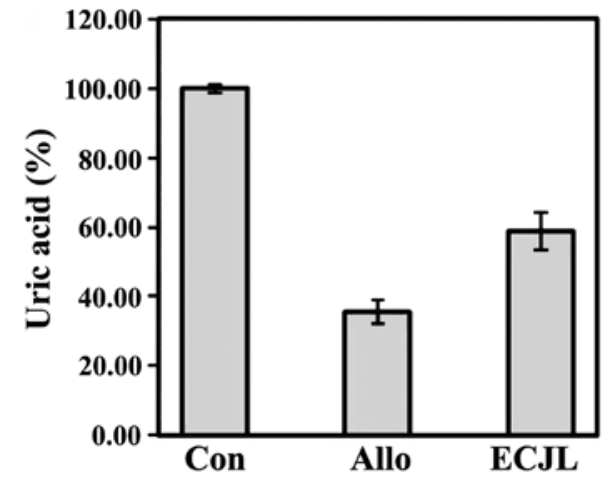

Figure 1.XO inhibitory activity of ECJL in vitro. Inhibitory effects by $30 \mu \mathrm{g} / \mathrm{ml}$ allopurinol, $2 \mathrm{mg} / \mathrm{ml}$ ECJL. Each value is represented as the mean $\pm \mathrm{SD}$ of 3 separate experiments in triplicate measurements. $\mathrm{XO}$, xanthine oxidase; ECJL, extracts of $C$. japonica leaf.

Table III. Antioxidant activities of ECJL.

\begin{tabular}{lccc}
\hline & $\begin{array}{c}\mathrm{DPPH} \\
\mathrm{IC}_{50} \\
(\mu \mathrm{g} / \mathrm{ml})\end{array}$ & $\begin{array}{c}\text { Total phenol } \\
(\mathrm{mg} / \mathrm{g} \text { eq. } \\
\text { gallic acid })\end{array}$ & $\begin{array}{c}\text { Reducing power } \\
(\text { ascorbic acid eq. } \\
\mu \mathrm{g} / 50 \mu \mathrm{g} \text { ECJL) }\end{array}$ \\
\hline ECJL & $\begin{array}{c}38.53 \pm 0.72 \\
\text { Ascorbic acid }\end{array}$ & $6.95 \pm 0.6 \pm 1.6$ & $13.34 \pm 1.7$ \\
\hline
\end{tabular}

ECJL, extracts of $C$. japonica leaf.

Determination of XO inhibitory activity in vivo. The residual activity of $\mathrm{XO}$ in the mouse liver and plasma were spectrophotometrically determined by monitoring uric acid formation from xanthine (12). The mouse livers $(0.5 \mathrm{~g})$ were homogenized in an $1 \mathrm{ml}$ aliquot of $50 \mathrm{mM}$ sodium phosphate buffer ( $\mathrm{pH}$ 7.4). The homogenates were centrifuged at $3,000 \mathrm{xg}$ for $10 \mathrm{~min}$ at $4^{\circ} \mathrm{C}$. After removing the lipid layer, the supernatant was centrifuged at $10,000 \mathrm{x}$ g for $60 \mathrm{~min}$ at $4^{\circ} \mathrm{C}$. The resultant supernatant was then used for determining $\mathrm{XO}$ residual activity and the total protein concentration. A $0.12 \mathrm{ml}$ aliquot of xanthine solution $(250 \mathrm{mM})$ was added to a test tube containing $10 \mu \mathrm{l}$ liver homogenate and $0.54 \mathrm{ml}$ potassium oxonate solution $(1 \mathrm{mM})$ in $50-\mathrm{mM}$ sodium phosphate buffer ( $\mathrm{pH} 7.4)$ that were previously incubated at $35^{\circ} \mathrm{C}$ for $15 \mathrm{~min}$. The reaction was termined after 0 and $30 \mathrm{~min}$ by the addition of a $0.1 \mathrm{ml}$ aliquot of $0.6 \mathrm{M} \mathrm{HCl}$. Thereafter, the test tube was centrifuged at $3,000 \mathrm{xg}$ for $5 \mathrm{~min}$, and the absorbance of the supernatant was measured at $295 \mathrm{~nm}$ using a UV/VIS spectrophotometer (Biochrom Libra S12; serial no. 116997; Biochrom Ltd., Cambridge, UK). The total protein concentration was determined spectrophotometrically by the Bradford method (21). $\mathrm{XO}$ activity was expressed as micromoles of uric acid formed per minute $(\mathrm{U})$ per milligram protein.

Statistical analysis. A value of $\mathrm{P}<0.05$ was considered to indicate a statistically significant difference and was determined using a t-test between the two means for the unpaired data or an ANOVA (post hoc test: Tukey's multiple range test) among the 3 or more means for the unpaired data. All data were expressed as the means \pm standard deviation and rounded to 2 decimal places.

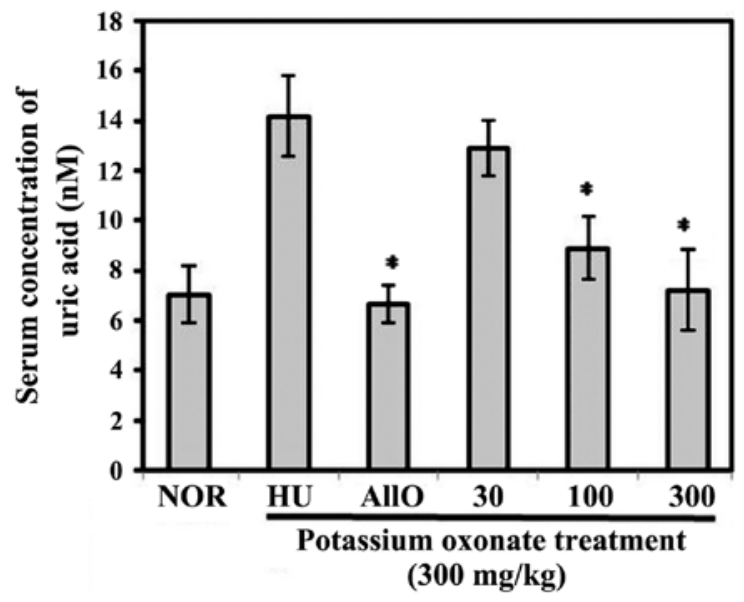

Figure 2. Serum uric acid levels following the oral administration of saline in normal mice (NOR) or following the oral administration of saline (HU), allopurinol at a dose of $10 \mathrm{mg} / \mathrm{kg}$ (ALLO) or ECJL at a dose of $30 \mathrm{mg} / \mathrm{kg}$ (30), $100 \mathrm{mg} / \mathrm{kg}$ (100) or $300 \mathrm{mg} / \mathrm{kg}$ (300) in mice with potassium oxonate-induced hyperuricemia over a period of 7 days. The rectangular bars and their error bars represent the means $\pm \mathrm{SD}$, respectively $(\mathrm{n}=5)$. * Significantly different from other groups ( $\mathrm{p}<0.05$, ANOVA a posteriori Tukey's multiple range test). ECJL, extracts of $C$.japonica leaf.

\section{Results}

Antioxidant activity and total phenolic contents of ECJL. The antioxidant potential of ECJL was determined by DPPH and reducing power assays. Plants have been reported to be useful sources of phytochemicals, such as phenolics, and various health benefits, such as antioxidant activity have been suggested (22). In addition, the various antioxidant activities of natural resources significantly correlate with their major compound contents, such as polyphenols. Therefore, in this study, we determined the total phenolic contents of the extract obtained from ECJL.

The DPPH scavenging effect is a widely used method to evaluate the free radical scavenging ability of plant extracts. Table III shows the measured DPPH radical scavenging activity. A low $\mathrm{IC}_{50}$ value indicates a strong antioxidant activity in ECJL. The $\mathrm{IC}_{50}$ value of the extract was $38.53 \pm 0.72 \mu \mathrm{g} / \mathrm{ml}$.

$\mathrm{Fe}^{3+}$ was transformed into $\mathrm{Fe}^{2+}$ in the presence of extracts to measure the reductive capability. At $50 \mu \mathrm{g} / \mathrm{ml}$ of the extract, the value, which is expressed in vitamin $\mathrm{C}$ equivalents, of the reducing power of vitamin $\mathrm{C}$ was $13.34 \pm 1.7 \mu \mathrm{g} / 50 \mu \mathrm{g}$ ECJL.

Total phenol compounds, as determined by the FolinCiocalteu method, as previously described (17), are reported as gallic acid equivalents by reference to a standard curve $\left(r^{2}=0.999\right)$. Table III shows the total phenolic content of the extract. The amount of the phenolic compounds in the extract was $46.6 \pm 1.6 \mathrm{mg} / \mathrm{g}$ eq. gallic acid.

$X O$ inhibitory activity of ECJL in vitro. Fig. 1 shows the XO inhibitory activity of ECJL. XO inhibitory activity was expressed as the suppression rate of uric acid production. Allopurinol (as a positive control) at a concentration of $30 \mu \mathrm{g} / \mathrm{ml}$ significantly inhibited XO activity by $64.6 \pm 3.4 \%$. Notably, the dose-dependent XO inhibitory activity of ECJL significantly increased. ECJL at a concentration of $2 \mathrm{mg} / \mathrm{ml}$ inhibited XO activity by $41.3 \pm 5.5 \%$. 


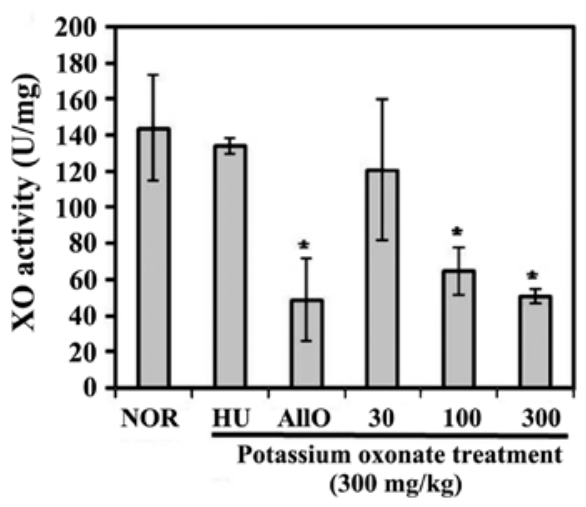

Figure 3. Hepatic XO activity following the oral administration of saline in normal mice (NOR) or following the oral administration of saline (HU), allopurinol at a dose of $10 \mathrm{mg} / \mathrm{kg}$ (ALLO) or ECJL at a dose of $30 \mathrm{mg} / \mathrm{kg}$ (30), $100 \mathrm{mg} / \mathrm{kg}(100)$ or $300 \mathrm{mg} / \mathrm{kg}$ (300) in mice with potassium oxonate-induced hyperuricemia over a peiod of 7 days. The rectangular bars and their error bars represent the means \pm SD, respectively $(n=5)$. "Significantly different from the $\mathrm{HU}$ group ( $\mathrm{p}<0.05$, ANOVA a posteriori Tukey's multiple range test). XO, xanthine oxidase; ECJL, extracts of $C$. japonica leaf.

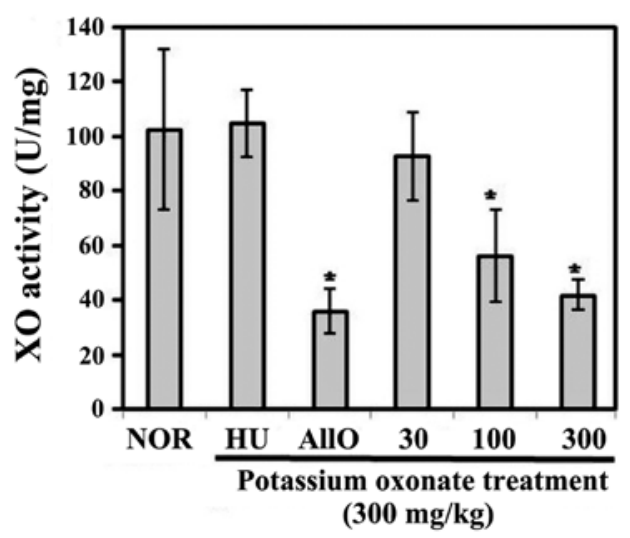

Figure 4. Serum XO activity following the oral administration of saline in normal mice (NOR) and after oral administration of saline (HU), allopurinol at a dose of $10 \mathrm{mg} / \mathrm{kg}$ (ALLO) or ECJL at a dose of $30 \mathrm{mg} / \mathrm{kg}(30), 100 \mathrm{mg} / \mathrm{kg}$ (100) or $300 \mathrm{mg} / \mathrm{kg}$ (300) in mice with potassium oxonate-induced hyperuricemia over a period of 7 days. The rectangular bars and their error bars represent the means $\pm S D$, respectively $(n=5)$. "Significantly different from the HU group ( $\mathrm{p}<0.05$, ANOVA a posteriori Tukey's multiple range test). XO, xanthine oxidase; ECJL, extracts of $C$. japonica leaf.

Anti-hyperuricemic effects of the extract in vivo: serum uric acid levels. Fig. 2 shows the effects of ECJL on the serum uric acid levels in mice with potassium oxonate-induced hyperuricemia. The concentrations were significantly higher in the mice with hyperuricemia compared to the normal mice, indicating that the mouse model of hyperuricemia was successfully established at $1 \mathrm{~h}$ after the intraperitoneal injection of potassium oxonate, a urate oxidase inhibitor, which is consistent with the findings of a previous study (20). The serum uric acid concentrations in the normal mice were comparable with those in the hyperuricemic mice that were administered allopurinol or the 3 different doses of ECJL (30, 100 and $300 \mathrm{mg} / \mathrm{kg}$ over a period of 7 days.

In our in vivo model, the level of serum uric acid was effectively increased by potassium oxonate at a dose of $300 \mathrm{mg} / \mathrm{kg}$ via intraperitoneal injection $(14.19 \pm 1.62 \mu \mathrm{M})$. The serum levels of uric acid in the allopurinol-treated group and ECJL treatment groups $(30,100,300 \mathrm{mg} / \mathrm{kg}$ ) were $6.65 \pm 0.74,12.89 \pm 1.13$, $8.89 \pm 1.17$ and $7.23 \pm 1.63 \mu \mathrm{M}$, respectively. Allopurinol at a dose of $10 \mathrm{mg} / \mathrm{kg}$ suppressed the serum uric acid levels by $53 \%$ and ECJL at a dose of $300 \mathrm{mg}$ significantly suppressed the uric acid levels by $49.1 \%$, similar to allopurinol.

Anti-hyperuricemic effects in vivo: hepatic and serum $X O$ activity. Figs. 3 and 4 show the effects of ECJL on the hepatic and serum XO activity in the mice with potassium oxonate-induced hyperuricemia. Pre-treatment with allopurinol for 1 week (oral administration) and ECJL at the doses of 100 and $300 \mathrm{mg} / \mathrm{kg}$ significantly reduced hepatic XO activity by $66.1,55.2$ and $64.7 \%$, respectively (Fig. 3). Similarly, the serum XO activity in the mice pre-treated orally with allopurinol and ECJL at the doses of 100 and $300 \mathrm{mg} / \mathrm{kg}$ was reduced by $65,45.2$ and $59.3 \%$, respectively.

However, there were no significant differences in hepatic and plasma XO activity between the normal and hyperuricemic control groups. Taken together, our findings demonstrated that ECJL at the dose of $300 \mathrm{mg} / \mathrm{kg}$ exerted XO inhibitory activity similar to that of allopurinol at a dose of $10 \mathrm{mg} / \mathrm{kg}$.

$X O$ inhibitory activity of the main components identified from $E C J L$. In the present study, we identified active compounds related to XO inhibitory activity from $C$. japonica leaf using GC-MS and liquid chromatography analysis. We identified one XO inhibitor, namely rutin $(5.87 \%)$ using liquid chromatography. We identified 8 active compounds, which were vitamin $\mathrm{E}(25.35 \%)$ n-eicosane $(10.2 \%)$, neophytadiene $(0.91 \%)$, all trans-squalene (3.32\%), n-octacosane (2.65\%), 6,9-pentadecadien-1-ol (1.51\%), $\alpha$-linolenic acid (1.41\%), and n-hexadecanoic acid $(0.61 \%)$ using GC-MS.

Figs. 5 and 6 show typical GC-MS and HPLC chromatograms, respectively, which show the phytochemical constituents. After clarifying the active substances, we expected that the potent XO inhibitory activity of ECJL was due to the synergism of antioxidant and $\mathrm{XO}$ inhibitory substances.

\section{Discussion}

In our preliminary experiments, we screened 500 plant extracts, and selected ECJL as a candidate for an $\mathrm{XO}$ inhibitor. We fractionated the extract using solvent extraction and found that the ethanol fraction (ECJL) exhibited the most prominent XO inhibitory activity in water/ethanol extraction. The ethanol fraction exhibited strong DPPH radical scavenging activity and reducing power (unpublished data). Based on these results, the ethanol fraction was selected for further in vitro and in vivo experiments.

Our results revealed that total phenolics were enriched in ECJL. Phenolics have been shown to possess antioxidant and anti-inflammatory activities (23).

A number of phenolics have been shown to possess antioxidant and XO inhibitory activity, and to have the ability to decrease uric acid levels in serum. Thus, the solvent extraction condition was optimized with respect to the antioxidant and XO inhibitory activity (unpublished data). Table III shows that ECJL contained phenolic compounds (46.6 $\pm 1.6 \mathrm{mg} / \mathrm{g}$ eq. gallic acid). 


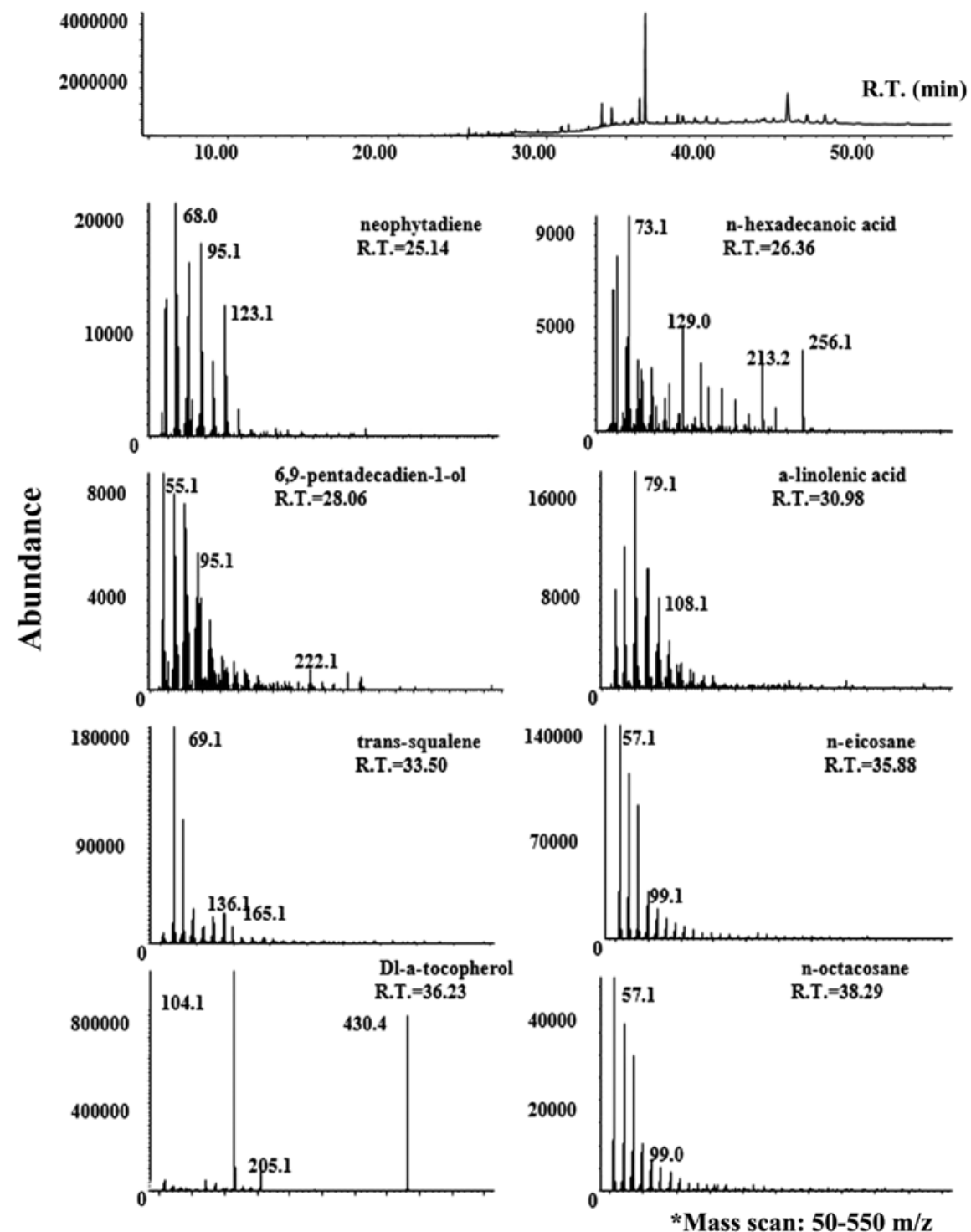

Figure 5. Representative GC-MS chromatogram showing the bioactive constituent profiles of ECJL. GC-MS, gas chromatography-mass spectrometry; ECJL, extracts of $C$. japonica leaf.
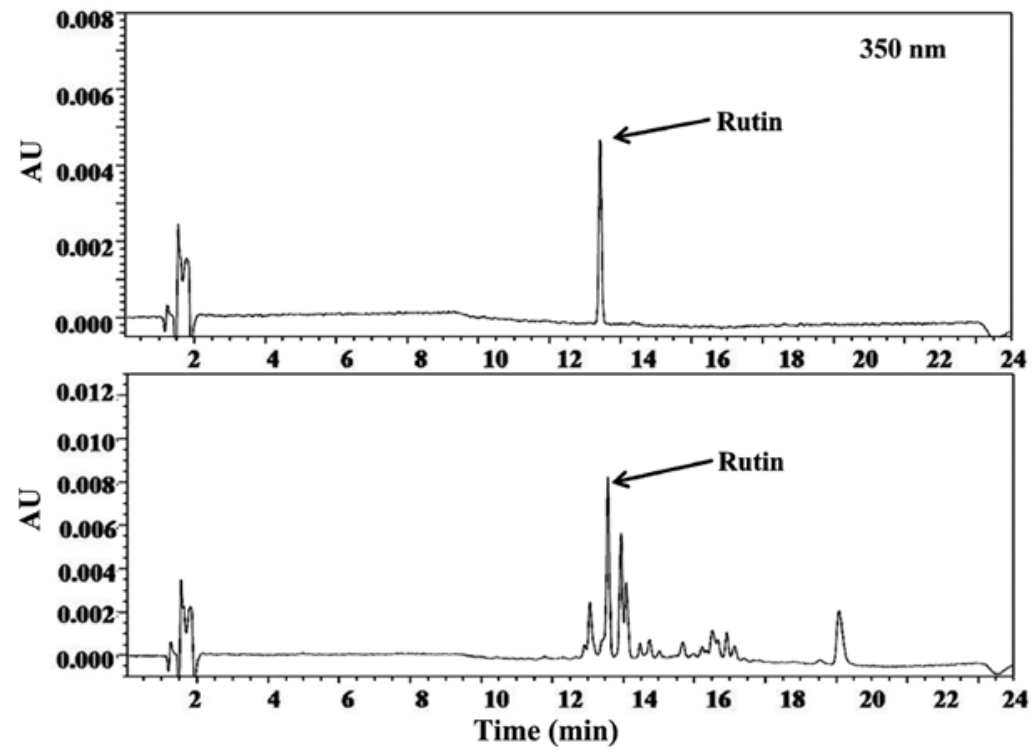

Figure 6. Representative HPLC chromatogram showing the bioactive constituent profiles of ECJL (RUT: rutin). HPLC high-performance liquid chromatography; ECJL, extracts of $C$. japonica leaf. 
Hyperuricemia is an abnormal condition which involves high levels of uric acid, and the major factor is known to be the overproduction of uric acid by XO (24). In general, the extract that has antioxidant activity is closely related to $\mathrm{XO}$ inhibitory activity and the recovery of oxidative damage. The breakdown of purine metabolism is known to be responsible for hyperuricemia. Hyperuricemia is mainly caused by decreased renal uric acid excretion or excessive hepatic uric acid generation (25). $\mathrm{XO}$ can catalyze the oxidation of hypoxanthine to uric acid, primarily in the liver (26). Gout is a representative disease that is closely related to hyperuricemia. Excessive levels of serum uric acid are the main risk factors for uric acid crystal deposition in joints and kidneys, resulting in uric acid nephrolithiasis and gouty arthritis (27). Thus, the serum uric acid level and hepatic $\mathrm{XO}$ activity were evaluated to examiney the anti-hyperuricemic effects of ECJL that was prepared in this study.

Figs. 2-4 show that ECJL at doses of 100 and $300 \mathrm{mg} / \mathrm{kg}$ significantly reduced the serum uric acid levels and inhibited the hepatic and serum XO activity. These results clearly indicate that the oral administration of ECJL markedly attenuates the hyperuricemic state in mice. In particular, there were no significant differences in hepatic and serum XO activity between the normal and hyperuricemic control groups. This result suggests that intraperitoneal pre-treatment with potassium oxonate, a known uricase inhibitor, may not affect $\mathrm{XO}$ activity in mice. Thus, ECJL controls hyperuricemia via the inhibition of $\mathrm{XO}$ in the liver and serum in potassium oxonatetreated mice.

The mechanisms of action of ECJL could be explained through analytical study of the active constituents in ECJL. Fig. 5 shows that we identified the important bioactive markers related to antioxidant activity and hyperuricemi, such as vitamin E $(25.35 \%)$, neophytadiene $(0.91 \%)$, all trans-squalene $(3.32 \%), \alpha$-linolenic acid $(1.41 \%)$, n-eicosane $(10.2 \%)$, n-octacosane (2.65\%), 6,9-pentadecadien-1-ol (1.51\%), and n-hexadecanoic acid $(0.61 \%)$ using GC-MS.

Vitamin E was the major compound in ECJL. Catignani et al found that the increase in XO activity in the liver was due to the level of vitamin $\mathrm{E}$ and involved the accumulation of the enzyme protein in vitamin E-deficient rabbits (28). Mohd Fahami et al reported that palm vitamin $\mathrm{E}$ also reduced $\mathrm{XO}$ acitivity in gastric regions (29). Thus, vitamin E may be the first key compound as a strong antioxidant agent and XO regulator in ECJL.

Squalene has been reported to possess antioxidant properties. Huang et al reported that squalene is a highly effective oxygen-scavenging agent (30).

Among the identified fatty acids, linolenic acid was analyzed. Park et al reported that linolenic acid downregulated inducible nitric oxide synthase (iNOS) and cyclooxygenase-2 (COX-2) expression and thereby reduced nitric oxide (NO) and prostaglandin E2 production in lipopolysaccharide (LPS)-activated RAW264.7 cells. These findings indicate the potential therapeutic use of linolenic acid as an anti-inflammatory agent (31). Linolenic acid is not closely related to hyperuricemia. Besides, linolenic acid affects secondary inflammatory damage, such as uric acid nephrolithiasis and gouty arthritis.

Fig. 6 shows that we identified rutin as an XO inhibitor using bioassay-guided liquid chromatography. The content of rutin in ECJL was determined to be $5.87 \%$ (w/w). A previous study reported that rutin at the dose of $50-100 \mathrm{mg} / \mathrm{kg}$ significantly decreased the biomarkers of serum urate, creatinine and blood urea nitrogen and serum, and kidney uromodulin levels in hyperuricemic mice (32). Azuma et al reported that 5 flavonoids were purified from the buthanol extract of C. japonica leaf and identified them as quercetin, kaempferol, apigenin, rutin and quercetrin (33). Previous studies have reported that quercetin inhibits $\mathrm{XO}$ activity in a competitive manner, while apigenin inhibits it in a mixed manner $(20,34)$. As shown in a previous sudy, rutin, when administered orally to mice with oxonate-induced hyperuricemia, was able to draw out dose-dependent hypouricemic effects by exerting significant inhibitory effects on xanthine dehydrogenase/xanthine oxidase (XDH/XO) activities (35). In the present study, we identified rutin by liquid chromatography. Considering previous reports of active markers and purification techniques, further studies are warranted for the isolation and identification of active compounds from ECJL.

Allopurinol is commonly used to treat and control hyperuricemia. However, its use can cause side-effects to patients, and these are reported as the main cause for the termination of anti-hyperuricemic therapy. This necessitates an alternative herbal medicine that is therapeutically effective for hyperuricemia and gout (12). In the present study, we aimed to evaluate the anti-hyperuricemic activities of ECJL, and to determine the optimal dosage in experimental models in vivo to predict oral administration in humans. ECJL was effective in reducing uric acid levels and inhibiting liver/serum XO activity, which indicates that ECJL may exert its anti-hyperuricemic effects mainly through this mechanism. ECJL reduced uric acid levels at two evaluated doses, at $100-300 \mathrm{mg} / \mathrm{kg}$, significantly inhibiting liver and serum $\mathrm{XO}$ activity.

In general, we considered the oral intake of dried Camellia japonica leaf of $10 \mathrm{~g}$ daily for the treatment of gout. Due to the yield of extract being $14.17 \%$, the oral dose for a human weighing $60 \mathrm{~kg}$ is $1,417 \mathrm{mg} /$ day $(23.61 \mathrm{mg} / \mathrm{kg} /$ day $)$. The conversion factor between humans and mice is 12.33 (36). Therefore, if the effective dose for mice is $300 \mathrm{mg} / \mathrm{kg} / \mathrm{day}$, the human equivalent dose is $1,459.85 \mathrm{mg} / 60 \mathrm{~kg} /$ day as ECJL, or $10.3 \mathrm{~g} / 60 \mathrm{~kg} /$ day as dried Camellia japonica leaf. In the present study, mice with hyporuricemia were treated with 30, 100 and $300 \mathrm{mg} / \mathrm{kg}$ ECJL and the effective oral dose was drawn in the range of $100-300 \mathrm{mg} / \mathrm{kg}$. We concluded that the oral intake of 3-10 $\mathrm{g}$ of $C$. japonica leaf is beneficial to prevent and/or decrease the possibility of the occurrence of hyperuricemia related disease.

Taken together, we found beneficial effects of ECJL from the results of biological evaluation through antioxidant assay and $\mathrm{XO}$ assay in vitro and in vivo. We also identified the active compounds that contribute to the antioxidant, anti-inflammatory, and XO inhibitory properties of ECJL from the results of GC-MS and HPLC analysis. In the future, we aim to determine whether ECJL has beneficial effect on gouty arthritis.

In conclusion, in the present study, $C$. japonica leaf from Korea was selected based on the possibility of its development for plant medicine and/or functional food materials as an anti-hyperuricemic agent. Our study revealed that the ethanol extract of $C$.japonica leaf was a positive sample which exerts a potent XO inhibitory effect similar to that of allopurinol. This study is a significant contribution to the knowledge of bioactive markers from the $C$. japonica leaf as potential sources for the medical industry, and presents data to explain the effects of ECJL in the treatment of hyperuricemia. 


\section{References}

1. Yoshikawa M, Murakami T, Yoshizumi S, Murakami N, Yamahara $\mathbf{J}$ and Matsuda $\mathrm{H}$ : Bioactive saponins and glycosides. V. Acylated polyhydroxyolean-12-ene triterpene oligoglycosides, camelliasaponins A1, A2, B1, B2, C1, and C2, from the seeds of Camellia japonica L.: Structures and inhibitory activity on alcohol absorption. Chem Pharm Bull (Tokyo) 44: 1899-1907, 1996.

2. Yoshikawa M, Morikawa T, Asao Y, Fujiwara E, Nakamura S and Matsuda H: Medicinal flowers. XV. The structures of noroleanane- and oleanane-type triterpene oligoglycosides with gastroprotective and platelet aggregation activities from flower buds of Camellia japonica. Chem Pharm Bull (Tokyo) 55: 606-612, 2007.

3. Heo J: Dongui Bogam. Naeuiwon edition, Bubinmunhwasa publisher, Seoul, Korea, 1613.

4. Cha SS, Lee KE, Lee SH, Choi MJ and Shim JK: Decomposition and nutrient dynamics of leaf litter of Camellia japonica $\mathrm{L}$. in Korea. Korean J Environ Ecol 30: 110-117, 2016 (In Korean).

5. Hwang EJ, Cha YJ, Park MH, Lee JW and Lee SY: Cytotoxicity and chemosensitizing effect of Camellia (Camellia japonica) tea extracts. J Korean Soc Food Sci Nutr 33: 487-493, 2004 (In Korean).

6. Yang JL, Ha TK, Dhodary B, Pyo E, Nguyen NH, Cho H, Kim E and Oh WK: Oleanane triterpenes from the flowers of Camellia japonica inhibit porcine epidemic diarrhea virus (PEDV) replication. J Med Chem 58: 1268-1280, 2015.

7. Onodera K, Hanashiro K and Yasumoto T: Camellianoside, a novel antioxidant glycoside from the leaves of Camellia japonica. Biosci Biotechnol Biochem 70: 1995-1998, 2006.

8. Thao NT, Hung TM, Lee MK, Kim JC, Min BS and Bae K: Triterpenoids from Camellia japonica and their cytotoxic activity. Chem Pharm Bull (Tokyo) 58: 121-124, 2010.

9. Nagata T, Tsushida T, Hamaya E, Enoki N, Manabe S and Nishino C: Camellidins, antifungal saponins isolated from Camellia japonica. Agric Biol Chem 49: 1181-1186, 1985.

10. Park JC, Hur JM, Park JG, Hatano T, Yoshida T, Miyashiro H, Min BS and Hattori M: Inhibitory effects of Korean medicinal plants and camelliatannin $\mathrm{H}$ from Camellia japonica on human immunodeficiency virus type 1 protease. Phytother Res 16: 422-426, 2002.

11. Zhao M, Zhu D, Sun-Waterhouse D, Su G, Lin L, Wang X and Dong Y: In vitro and in vivo studies on adlay-derived seed extracts: Phenolic profiles, antioxidant activities, serum uric acid suppression, and xanthine oxidase inhibitory effects. J Agric Food Chem 62: 7771-7778, 2014.

12. Lemos Lima Rde C, Ferrari FC, de Souza MR, de Sá Pereira BM, de Paula CA and Saúde-Guimarães DA: Effects of extracts of leaves from Sparattosperma leucanthum on hyperuricemia and gouty arthritis. J Ethnopharmacol 161: 194-199, 2015.

13. Chu YH, Chen CJ, Wu SH and Hsieh JF: Inhibition of xanthine oxidase by Rhodiola crenulata extracts and their phytochemicals. J Agric Food Chem 62: 3742-3749, 2014.

14. Kramer HM and Curhan G: The association between gout and nephrolithiasis: The National Health and Nutrition Examination Survey III, 1988-1994. Am J Kidney Dis 40: 37-42, 2002.

15. Choi HJ, Lee CH, Lee JH, Yoon BY, Kim HA, Suh CH, Choi ST, Song JS, Joo HY, Choi SJ, et al: Current gout treatment and flare in South Korea: Prophylactic duration associated with fewer gout flares. Int J Rheum Dis: Aug 27, 2014 (Epub ahead of print).

16. Bae MS, Shin JS, Lee KY, Lee KH and Kim YJ: Long-range transport of biomass burning emissions based on organic molecular markers and carbonaceous thermal distribution. Sci Total Environ 466-467: 56-66, 2014.

17. Kim YH, Cho ML, Kim DB, Shin GH, Lee JH, Lee JS, Park SO, Lee SJ, Shin HM and Lee OH: The antioxidant activity and their major antioxidant compounds from Acanthopanax senticosus and A. koreanum. Molecules 20: 13281-13295, 2015.
18. Seo JH, Kim JE, Shim JH, Yoon G, Bang MA, Bae CS, Lee KJ, Park DH and Cho SS: HPLC analysis, optimization of extraction conditions and biological evaluation of Corylopsis coreana Uyeki flos. Molecules 21: 94, 2016.

19. Arimboor R, Rangan M, Aravind SG and Arumughan C: Tetrahydroamentoflavone (THA) from Semecarpus anacardium as a potent inhibitor of xanthine oxidase. J Ethnopharmacol 133: 1117-1120, 2011.

20. Huo LN, Wang W, Zhang CY, Shi HB, Liu Y, Liu XH, Guo BH, Zhao DM and Gao H: Bioassay-guided isolation and identification of xanthine oxidase inhibitory constituents from the leaves of Perilla frutescens. Molecules 20: 17848-17859, 2015.

21. Bradford MM: A rapid and sensitive method for the quantitation of microgram quantities of protein utilizing the principle of protein-dye binding. Anal Biochem 72: 248-254, 1976.

22. Perron NR and Brumaghim JL: A review of the antioxidant mechanisms of polyphenol compounds related to iron binding. Cell Biochem Biophys 53: 75-100, 2009.

23. Liu LM, Cheng SF, Shieh PC, Lee JC, Chen JJ, Ho CT, Kuo SC, Kuo DH, Huang LJ and Way TD: The methanol extract of Euonymus laxiflorus, Rubia lanceolata and Gardenia jasminoides inhibits xanthine oxidase and reduce serum uric acid level in rats. Food Chem Toxicol 70: 179-184, 2014.

24. Wu XH, Yu CH, Zhang CF, Anderson S and Zhang YW: Smilax riparia reduces hyperuricemia in mice as a potential treatment of gout. Am J Chin Med 42: 257-259, 2014.

25. Gurwitz JH, Kalish SC, Bohn RL, Glynn RJ, Monane M, Mogun $\mathrm{H}$ and Avorn J: Thiazide diuretics and the initiation of anti-gout therapy. J Clin Epidemiol 50: 953-959, 1997.

26. Ardan T, Kovaceva J and Cejková J: Comparative histochemical and immunohistochemical study on xanthine oxidoreductase/xanthine oxidase in mammalian corneal epithelium. Acta Histochem 106: 69-75, 2004.

27. Grassi D, Ferri L, Desideri G, Di Giosia P, Cheli P, Del Pinto R, Properzi G and Ferri C: Chronic hyperuricemia, uric acid deposit and cardiovascular risk. Curr Pharm Des 19: 2432-2438, 2013.

28. Catignani GL, Chytil F and Darby WJ: Vitamin E deficiency: Immunochemical evidence for increased accumulation of liver xanthine oxidase. Proc Natl Acad Sci USA 71: 1966-1968, 1974.

29. Mohd Fahami NA, Ibrahim IA, Kamisah Y and Mohd Ismail N: Palm vitamin E reduces catecholamines, xanthine oxidase activity and gastric lesions in rats exposed to water-immersion restraint stress. BMC Gastroenterol 12: 54, 2012

30. Huang ZR, Lin YK and Fang JY: Biological and pharmacological activities of squalene and related compounds: Potential uses in cosmetic dermatology. Molecules 14: 540-554, 2009.

31. Park SY, Seetharaman R, Ko MJ, Kim DY, Kim TH, Yoon MK, Kwak JH, Lee SJ, Bae YS and Choi YW: Ethyl linoleate from garlic attenuates lipopolysaccharide-induced pro-inflammatory cytokine production by inducing heme oxygenase-1 in RAW264.7 cells. Int Immunopharmacol 19: 253-261, 2014.

32. Chen YS, Hu QH, Zhang X, Zhu Q and Kong LD: Beneficial effect of rutin on oxonate-induced hyperuricemia and renal dysfunction in mice. Pharmacology 92: 75-83, 2013.

33. Azuma CM, dos Santos FCS and Lago JHG: Flavonoids and fatty acids of Camellia japonica leaves extract. Rev Bras Farmacogn 21: 1159-1162, 2011.

34. Pauff JM and Hille R: Inhibition studies of bovine xanthine oxidase by luteolin, silibinin, quercetin, and curcumin. J Nat Prod 72: 725-731, 2009.

35. Zhu JX, Wang Y, Kong LD, Yang C and Zhang X: Effects of Biota orientalis extract and its flavonoid constituents, quercetin and rutin on serum uric acid levels in oxonate-induced mice and xanthine dehydrogenase and xanthine oxidase activities in mouse liver. J Ethnopharmacol 93: 133-140, 2004.

36. Shin JW, Seol IC and Son CG: Interpretation of animal dose and human equivalent dose for drug development. J Korean Orient Med 31: 1-7, 2010 